49 Reed. R.H., Richardson, D.L., Warr, S.R.C., and Stewart, W.D.P., Carbohydrate accumulation and osmotic stress in cyanobalcteria. J. gen. Microbiol. 130)(1984) I 4

50) Reistad, R., On the composition and nature of the bulk protein of extremely halophilic bacteria. Archs Microbiol. 71 (1970) 353-360.

5I Rodriguez-Valera, F., Juez, G., and Kushner, D. J., Halobacterium mediterranci spec.nov., a new carbohydrate-utilizing extreme halophile. Syst. appl. Microbiol. 4 (1983) 369381.

52 Ross, H. N. M., and (irant, W. D., Nucleic acid studies on halophilic archachacteria. J. gen. Microbiol. $13 /$ (1985) 165173.

53 Schleiden, M.J., Das Salz. Verlag Wilhelm Engelmann, Leipzig 1875 .

54 Schuh, W., Puff, H., Galinski, E. A., and Trüper, H. G., Die Kristallstruktur des Letoin, einer nelien osmoregulatorisch wirksamen Aminosäure. Z. Naturf. 40) (1985) 780) 784.

55 Shindler, D. B., Wydro, R. W., and Kushner, D. J., Cell-bound cations of the moderately halophilic bacterium, Vibrio costicola. J. Bact. 1.30 (1977) 698703

56 Shkedy-Vinkler, ('., and Avi-Dor, Y., Betaine-induced stimulation of respiration at high osmolarities in a halotolerant bacterium. Biochem. J. $1.50(1975) 219226$.

57 Tindill. B.J., Phototrophic bacteria from Kenyan soda lakes. Doctoral thesis, Univ. Leicester, UK 1980

s8 Tindall, B.J. Life in the alkaline saline athalassic environment, in: The Halophilic Bacteria. Ed. F. Rodrigues-Valera. CRC Uniscience Suries, C RC Press, Boca Raton, Florida, USA (1986) in press.

5) Tindall, B. J., and Trüper, H. G., Ecophysiology of the aerobic halophilic archacbactcria. Syst. appl. Microbiol. 7 (1986) 202212.

(n) Tomlinson, (. A., and Hochstein, L. I., lsolation of carbohydratemetabolizing. extremely halophilic bacteria. Can. J. Microbiol. 18 (1972) 698701
61 Ventosa, A., Quesada, E., Rodriguez-Valera, F., and Ramos-Cormenzana, A., Numerical taxonomy of moderately halophilic Gramnegative rods. J. gen. Microbiol. I28 (1982) 1959-1968.

62 Villar, M., de Ruiz Holgado, A. P., Sanchez, J. J., Trucco, R. E., and Oliver, G., Isolation and characterization of Pediococcus halophilus from salted anchovies (Engraulis anchoita). Appl. envir. Microbiol. 49 (1985) 664-666

63 Visentin, L.P., Chow, C., Matheson. A. T., Yaguchi, M., and Rollin F., Halobacterium cutirubrum ribosomes. Properties of the ribosomal proteins and ribonucleic acid. Biochem. J. 130 (1972) $103 \quad 110$.

64 Volcani, B.E., Studies on the microflora of the Dead Sea. Doctoral thesis, Hebrew Univ., Jerusalem, 1940.

65 Vreeland, R. H., Litchfield, C. D., Martin, E. L., and Elliot, E., Halomonas elongata, a new genus and species of extremely salt-tolerant bacteria. Int. J. syst. Bact. 30 (1980) 485-495.

66 Weisser, J., and Trüper, H.G., Osmoregulation in a new haloalkaliphilic Bacillus from the Wadi Natrun (Egypt). Syst. appl. Microbiol. $6(1985) 7-14$.

67 Yopp, J.H., The role of sulfur in osmoregulation and salinity tolerance in cyanobacteria, algae, and plants, in: The Global Sulfur $\mathrm{Cy}$ cle, pp. 83-86. Ed. D. Sagan. NASA Technical Memorandum 87570 (1985).

68 Zeikus, J.G., Hegge, P.W., Thompson, T.E., Phelps, T.J., and Langworthy, T.A:, Isolation and description of Haloanacrobium praevalens gen.nov. and spec.nov., an obligately anacrobic halophile common to Great Salt Lake sediments. Curr. Microbiol. 9 (198.3) $225-234$.

$0014-4754 / 86 / 11 / 121182-06 \$ 1.50+0.20 / 0$

(C) Birkhäuser Verlag Basel, 1986

\title{
Life above the boiling point of water?
}

\author{
by K. O. Stetter, G. Fiala, R. Huber, G. Huber and A. Segerer
}

L.ehrstuhl für Mikrobiologie. Universität Regensburg, D-8400 Regensburg (Federal Republic of Germany)

Summarl: Various extremely thermophilic archaebacteria exhibit optimum growth at above $80^{\circ} \mathrm{C}$. Pyrodictium is the most thermophilic of these organisms, growing at temperatures of up to $110^{\circ} \mathrm{C}$ and exhibiting optimum growth at about $105^{\circ} \mathrm{C}$. All of these organisms grow by diverse types of anaerobic and aerobic metabolism.

Key words. Archacbacteria; thermophilic bacteria; Pyrodictium.

\section{Introduction}

For a long lime, thermophilic bacteria with temperature optima above $45^{\circ} \mathrm{C}$ have been recognized to be widely distributed in soils, self-heated hay, and geothermally heated areas. Most of them show an upper temperature limit of growth between 60 and $80^{\circ} \mathrm{C}$ and are members of genera also containing mesophiles, such as Bacillus and Clostridium. About 15 years ago, bacteria living in the hot springs of Yellowstone National Park were observed ${ }^{3}$ and the first extremely thermophilic organism with a temperature maximum at $85^{\circ} \mathrm{C}$ was isolated ${ }^{4}$. Since that time, various extremely thermophilic bacteria with temperature optima well above $80^{\circ} \mathrm{C}$ were obtained which, as a rulc, do not grow at 60$)^{\circ}$ ( or below. Prodictium, the most extreme thermophilic organism existing in pure cullure does nol even grow at $82^{\circ} \mathrm{C}$ or below". Almost all of these organisms (one exception ${ }^{\prime \prime \prime}$ ) belong to the methanogenic and $S^{\prime \prime}$-metabolizing archacbacteria ${ }^{23}$, the properlies of which are reviewed here.

\section{Habitats}

All the extremely thermophilic, methanogenic and $\mathrm{S}^{\circ}$ dependent archaebacteria isolated have been found in geothermal areas. Sulfur is formed there by the oxidation of $\mathrm{H}_{2} \mathrm{~S}$ and by the reaction of $\mathrm{H}_{2} \mathrm{~S}$ with $\mathrm{SO}_{2}$. Both of these gases are often present in volcanic exhalations ${ }^{22}$. Liquid water is one important requirement for life $\mathrm{e}^{3}$. The maximum temperatures for liquid water are pressure-dependent, and in deep-sea hydrothermal areas $2500 \mathrm{~m}$ below the surface water temperatures may exceed $3000^{\circ} \mathrm{C}^{5}$. Terrestrial solfataric springs and mud holes exhibit temperatures of up to $100^{\circ} \mathrm{C}$. They include neutral to weakly alkaline (pH 7-9) springs rich in $\mathrm{Cl}$ as well as acidic sulfate-rich water- or mudholes." 1". The examination of soil profiles within sollatara lickds in Iceland. Italy and the Azores showed that these water-eontaining soils typically consist of two layers which have quite different properties; there is an oxidized, strongly acidic ochrecolored upper layer of about $15.30 \mathrm{~cm}$ in thickness over- 


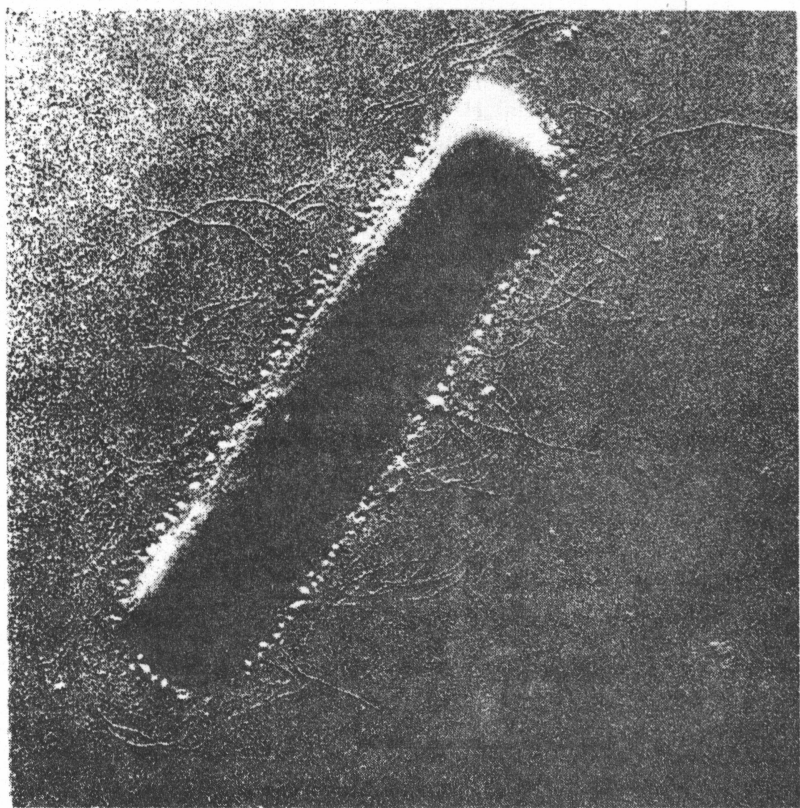

Figure 1. Isolate $\mathrm{H} 10$ grown at $100^{\circ} \mathrm{C}$. EM micrograph, Pt-shadowing. Bar $1 \mu \mathrm{m}$.

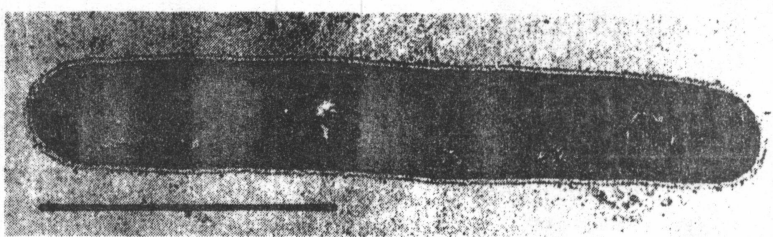

Figure 3. Methanothermus fervidus. EM micrograph, thin section. Bar I $\mu \mathrm{m}$.

Table 1. Growth temperatures of extremely thermophilic archacbacteria Species

Methanothermus sociabilis Acidianus infernus

Staphylothermus marinus Sulfolobus acidocaldarius

Pyrococcus furiosus Vc-1 Isolate $\mathrm{H} 10$

Thermodiscus maritimus

Thermofilum librum

Thermoproteus neutrophilus

Thermococcus celer

Pyrodictium occultum

\begin{tabular}{lcc}
$\begin{array}{l}\text { Growth temperature } \\
\text { Minimal }\end{array}$ & Optimal & Maximal \\
\hline 60 & 88 & 97 \\
60 & 88 & 95 \\
65 & 92 & 98 \\
60 & 80 & 90 \\
70 & 100 & 103 \\
75 & 100 & 102 \\
75 & 88 & 98 \\
70 & 80 & 95 \\
70 & 85 & 97 \\
75 & 88 & 97 \\
82 & 105 & 110 \\
\hline
\end{tabular}

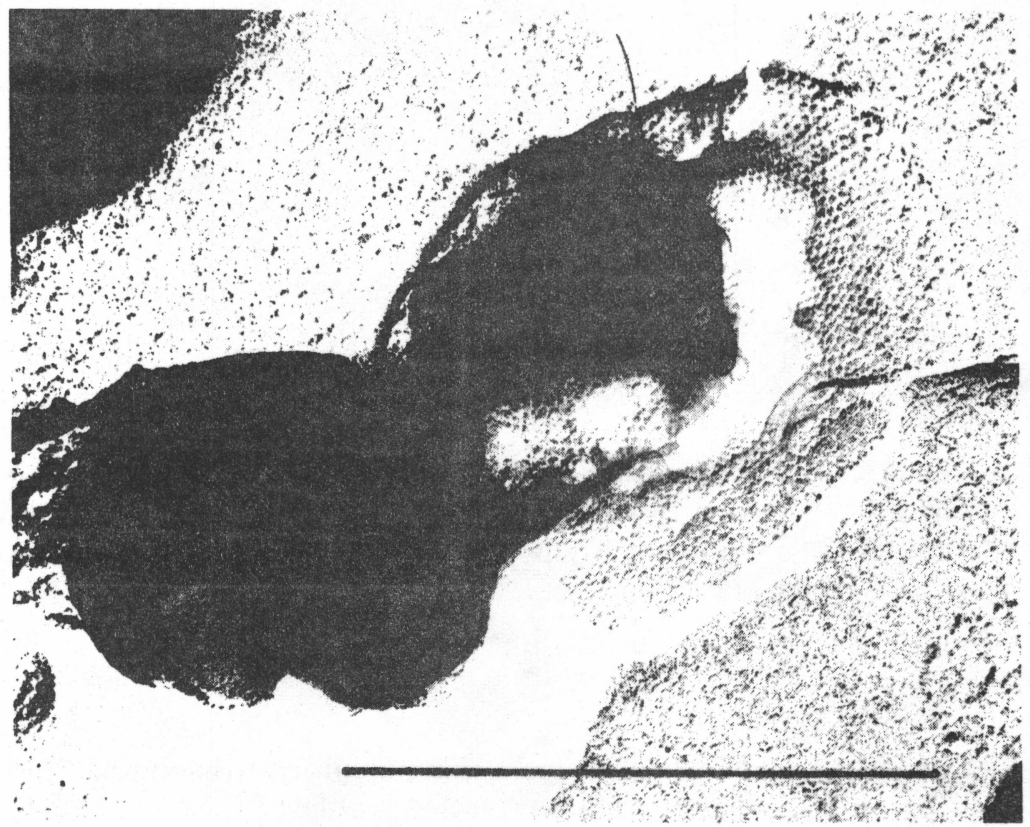

Figure 2. Extremely thermophilic ore-leaching isolate TH2. EM micrograph, Pt-shadowing. Bar $1 \mu \mathrm{m}$.

laying a reduced, bluish-black lower zone exhibiting a slightly acidic $\mathrm{pH}$ of between 4 and 6.5. In addition to their presence in natural habitats, extremely thermophilic archaebacteria also thrive within boiling outflows of geothermal powerplants in Larderello, Italy, and Krafla, Iceland.

With respect to their growth requirements, e.g. $\mathrm{pH}$, salts, possible substrates and high temperatures, extremely thermophilic archaebacteria appear to be well adapted to their natural environment. They are usually found to proliferate at temperatures between 60 and $98^{\circ} \mathrm{C}$ (table 1). We obtained isolate 'Geo 3' from the Krafla geothermal power plant. This organism resembles Thermoprot'us in shape (fig. 1) and metabolism but differs from the latter by its much lower GC-content and its upper growth temperature limit of $102^{\circ} \mathrm{C}$. The marine archaebacterium Pyrococcus furiosus shows a temperature optimum of growth at $100^{\circ} \mathrm{C}\left(38 \mathrm{~min}\right.$ doubling time $\left.{ }^{\prime \prime}\right)$. Pyrodictium grows at the highest temperatures found for any organism in the laboratory, exhibiting an optimum at $105^{\circ} \mathrm{C}$ and a maximum of approximately $110^{\circ} \mathrm{C}$. Due to its adaptation to the extremely high temperatures of its biotope, this organism is unable to grow at temperatures below $82^{\circ} \mathrm{C}^{17}$.

\section{Metabolism}

The extremely thermophilic methanogens grow exclusively by formation of methane from $\mathrm{H}_{2}$ and $\mathrm{CO}_{2}$, both 
1iable 2. Lnergy-yiclding reactions of extremely thermophilic archaebacteria

\begin{tabular}{|c|c|c|c|}
\hline Mode of nutrition & Metabolism & Energy-yielding reaction & Example \\
\hline \multirow[t]{4}{*}{ Lithoatutotrophic } & Methanogenesis & $4 \mathrm{H}_{2}+\mathrm{CO}_{2} \rightarrow \mathrm{CH}_{4}+2 \mathrm{H}_{2} \mathrm{O}$ & $\begin{array}{l}\text { Methanothermus sociabilis } \\
\text { Methanothermus fervidus } \\
\text { Methanococcus jannaschii }\end{array}$ \\
\hline & S/H Autotrophy & $\mathrm{H}_{2}+\mathrm{S} \rightarrow \mathrm{H}_{2} \mathrm{~S}$ & $\begin{array}{l}\text { Pyrodictium oc'ultum } \\
\text { Thermoproteus n'utrophilus } \\
\text { Thermoproteus tenax* } \\
\text { Acidianus infernus** }\end{array}$ \\
\hline & S-oxidation & $2 \mathrm{~S}+3 \mathrm{O}_{2}+2 \mathrm{H}_{2} \mathrm{O} \rightarrow 2 \mathrm{H}_{2} \mathrm{SO}_{4}$ & $\begin{array}{l}\text { Sulfolobus acidocaldarius* } \\
\text { Acidianus infernus** }\end{array}$ \\
\hline & Pyritc oxidation & $4 \mathrm{FeS}_{2}+15 \mathrm{O}_{2}+2 \mathrm{H}_{2} \mathrm{O} \rightarrow 2 \mathrm{Fe}_{2}\left(\mathrm{SO}_{4}\right)_{3}+2 \mathrm{H}_{2} \mathrm{SO}_{4}$ & Isolates TH2*; Kra23; VE2 \\
\hline \multirow[t]{3}{*}{ Heterotrophic } & S-respiration & Organic $[\mathrm{H}]+\mathrm{S} \rightarrow \mathrm{H}_{2} \mathrm{~S}$ & $\begin{array}{l}\text { Thermoproteus tenax* } \\
\text { Desulfurococcus mobilis } \\
\text { Thermofilum pendens }\end{array}$ \\
\hline & Unknown anaerobic & Yeast extract $\rightarrow \mathrm{CO}_{2}+$ ? & Thermodiscus maritimus \\
\hline & $\begin{array}{l}\text { Fermentation } \\
\text { O-respiration }\end{array}$ & $\begin{array}{l}\text { Yeast extr. } \rightarrow \text { acetate, isovalerate, } \mathrm{CO}_{2}+\text { ? } \\
\text { Organic }[\mathrm{H}]+\mathrm{O}_{2} \rightarrow 2 \mathrm{H}_{2} \mathrm{O}\end{array}$ & $\begin{array}{l}\text { Staphylothermus marinus } \\
\text { Sulfolohus acidocaldarius* }\end{array}$ \\
\hline
\end{tabular}

* facultatively autotrophic. ** facultatively acrobic.

gases present in volcanic exhalations ${ }^{18}$. The sulfur-dependent archacbacteria are able to obtain metabolic energy either by the oxidation or by the anaerobic reduction of elemental sulfur, or require $\mathrm{S}^{\circ}$ for anabolic reactions (table 2). Anacrobic conditions in the volcanic environment are maintained by the escaping gases (e.g. $\mathrm{CO}_{2}, \mathrm{SO}_{2}, \mathrm{H}_{2} \mathrm{O}$, $\left.\mathrm{H}_{2}, \mathrm{CO}\right)$.

The aerobic and facultatively aerobic acidophilic representatives of the genera Sulfolobus and Acidianus thrive by formation of sulfuric acid either autotrophically or mixotrophically, depending on the isolate ${ }^{4.14,25}$. Some Sulfolohus strains can also grow organotrophically ${ }^{3}$. Some recent extremely thermophilic isolates ${ }^{9}$ (table 2) are able to grow autotrophically on sulfidic ores, solubilizing heavy metals at temperatures of up to $95^{\circ} \mathrm{C}$ (fig. 2 ). Acidianus infermus is able to grow anaerobically via the formation of $\mathrm{H}_{2} \mathrm{~S}$ from $\mathrm{H}_{2}$ and $\mathrm{S}^{\circ}$ (table 2$)^{8.14}$.

The strictly anacrobic Thermoproteus tenax can grow autotrophically on $\mathrm{H}_{2}$ and $\mathrm{S}^{\circ}$ or heterotrophically on yeast extract, carbohydrates and simple organic compounds by means of sulfur respiration ${ }^{24}$. Pyrodictium oc('ultum is an obligate $\mathrm{S} / \mathrm{H}$ autotroph (table 2$)^{15}$.
The heterotrophic anaerobic $\mathrm{S}^{\circ}$-metabolizing archaebacteria consume organic material in the solfataric and hydrothermal areas ${ }^{19}$. Some fermentative organisms are also present in such biotopes, e.g. Staphylothermus marinus $^{7}$. Methanogenic bacteria are also very efficient $S^{\circ}$ reducers, some of them (e.g. Methanothermus) sharing the habitats of $\mathrm{S}^{\circ}$-metabolizing archaebacteria ${ }^{13.16}$.

\section{Morphology}

The sulfur-metabolizing archaebacteria are variously coccoid, rod- or plate-shaped (table 3). Coccoid and plate-shaped cells are often highly variable in size even within the same culture. The rod-shaped Thermoproteus and Thermofilum form 'normal' cells of about $15 \mu \mathrm{m}$ in length or filaments more than $100 \mu \mathrm{m}$ long depending upon growth conditions ${ }^{19}$. Cell division usually takes place by constriction (e.g. Thermococcus) or budding (e.g. Thermoproteus), but never by septa formation. $M$ ('thanothermus species are gram-positive and show a rigid cell wall composed of pseudomurein (fig. 3). All $\mathrm{S}^{\circ}$-metabolizing archaebacteria are gram-negative with enve-

Table 3. Morphology of extremely thermophilic archaebacteria

\begin{tabular}{|c|c|c|c|}
\hline Shape & Genus & Size $(\mu \mathrm{m})$ & Comments \\
\hline \multirow[t]{3}{*}{ Rods } & Methanothermus & $0.3-0.5 \varnothing ; 1-3 \mu \mathrm{m}$ & $\begin{array}{l}\text { Gram-positive; pseudomurein } \\
\text { covered by S-layer }\end{array}$ \\
\hline & Thermoproteus & $0.4-0.5 \varnothing ; 1-100 \mu \mathrm{m}$ & $\begin{array}{l}\text { Spheres protruding terminally; } \\
\text { true branchings }\end{array}$ \\
\hline & Thermofilum & $0.15-0.2 \varnothing: 1-100 \mu \mathrm{m}$ & $\begin{array}{l}\text { Spheres protruding terminally; } \\
\text { rarely truc branchings }\end{array}$ \\
\hline \multirow[t]{7}{*}{ Cincoid } & Sulfolobus & $0.8-2 \varnothing$; irregular & \\
\hline & Acidiamus & $\begin{array}{l}\text { Aerobic: } 11.5 \varnothing ; \\
\text { anacrobic: } 0.51 \varnothing \text { : irregular }\end{array}$ & \\
\hline & De'sulfurococeus & $0.5-1 \varnothing$ & D. mohilis is flagellated \\
\hline & Thermococcus & $1 \varnothing$ & Tuft of flagella \\
\hline & Staphylothermus & $0.51 \varnothing$ & $\begin{array}{l}\text { Grows in aggregates. Growth of } \\
\text { giant cells }(10 \mu \mathrm{m} \varnothing) \text { in the } \\
\text { presence of } 0.2 \% \text { yeast extract }\end{array}$ \\
\hline & Pyrodictium & $\begin{array}{l}\text { Plates: } 0.2 \text { thick; } 0.32 .5 \varnothing \\
\text { Filaments: } 0.040 .08 \varnothing \text {; up to } 40 \text { long }\end{array}$ & $\begin{array}{l}\text { Plate- to dish-shaped cells; network } \\
\text { formed; grows like a mold }\end{array}$ \\
\hline & Thermodiscus & 0.2 thick; $0.3 .3 \varnothing$ & Plate- to dish-shaped \\
\hline
\end{tabular}




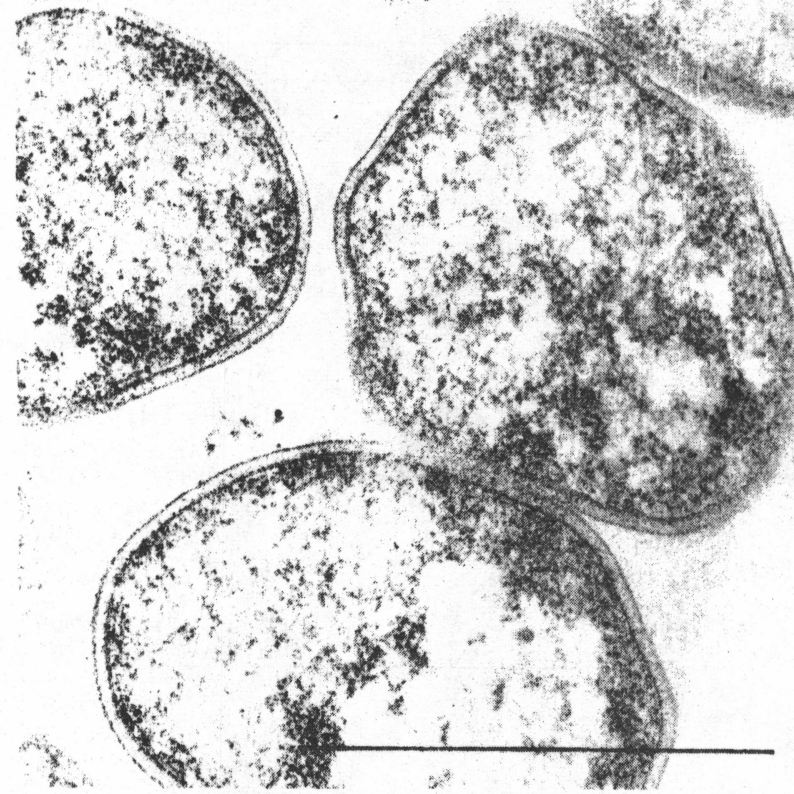

Figure 4. Acidiamus infernus. EM micrograph, thin section. Bar $1 \mu \mathrm{m}$.

lopes composed of protein subunits which cover their cytoplasmic membranes (fig. 4) ${ }^{11,12}$. Some coccoid (fig. 5) and rod-shaped isolates (fig. 1) are motile by means of flagella. Pyrodictium forms pellicles consisting of networks of fibers 0.04 to $0.08 \mu \mathrm{m}$ in diameter ${ }^{17}$, which entrap the cells during exponential growth (fig. 6).

\section{Prerequisites and limits of extremely thermophilic life}

Since some extremely thermophilic bacteria grow even in super-heated water, the question whether there is a general upper temperature limit for life arises. It depends primarily on the thermostability of cell components. The $\mathrm{S}^{\circ}$-metabolizing archaebacteria, which are the most thermophilic organisms known, are able to grow within a range of temperatures spanning approximately $30^{\circ} \mathrm{C}$ (table 1). This relatively narrow range may be due to the intrinsic properties of the cell material, e.g. the fluidity of the membranes and the optimal conformation of enzymes and nucleic acids. Possibly on account of this phenomenon, extremely thermophilic $\mathrm{S}^{\circ}$-metabolizers do not grow at temperatures below $60-82^{\circ} \mathrm{C}$, depending on the isolate (table 1). On the other hand, they are able to survive for years at low temperatures' ${ }^{17}$. The molecular stabilization mechanisms enabling growth at very high temperatures of up to $110^{\circ} \mathrm{C}$ are still unknown.

At temperatures of the order of $100^{\circ} \mathrm{C}$ even some low molecular weight compounds such as ATP and NAD hydrolize quite rapidly (half life below $30 \mathrm{~min}$ in vitro; Stetter, unpublished) and some thermolabile amino acids, e.g. cystein and, less markedly, glutamic acid, are decomposed ${ }^{2}$. The survival of organisms growing at these temperatures may be ensured by successful re-synthesis of sensitive compounds. This suggestion is in line with the observations that (a) maximal and optimal growth temperatures of Staphylothermus marinus are about $7^{\circ} \mathrm{C}$ lower in minimal medium than in full medium ${ }^{7}$ and (b) that Pyrodictium is rapidly killed at $110^{\circ} \mathrm{C}$ in the absence of substrate (Stetter, unpublished).

Under 'black smoker' conditions (e.g. $250^{\circ} \mathrm{C} ; 26 \mathrm{MPa}$ ) existing within hydrothermal deep-sea vents ${ }^{5}$, macromolecules and simple organic molecules, e.g. amino acids, are highly unstable (e.g. DNA: half life $20 \mu \mathrm{s}$ in

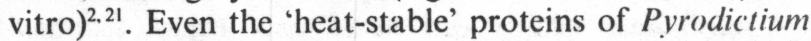
are rapidly decomposed under such extreme conditions? Despite an early report of bacterial growth at $250^{\circ} \mathrm{C}^{\prime}$ life

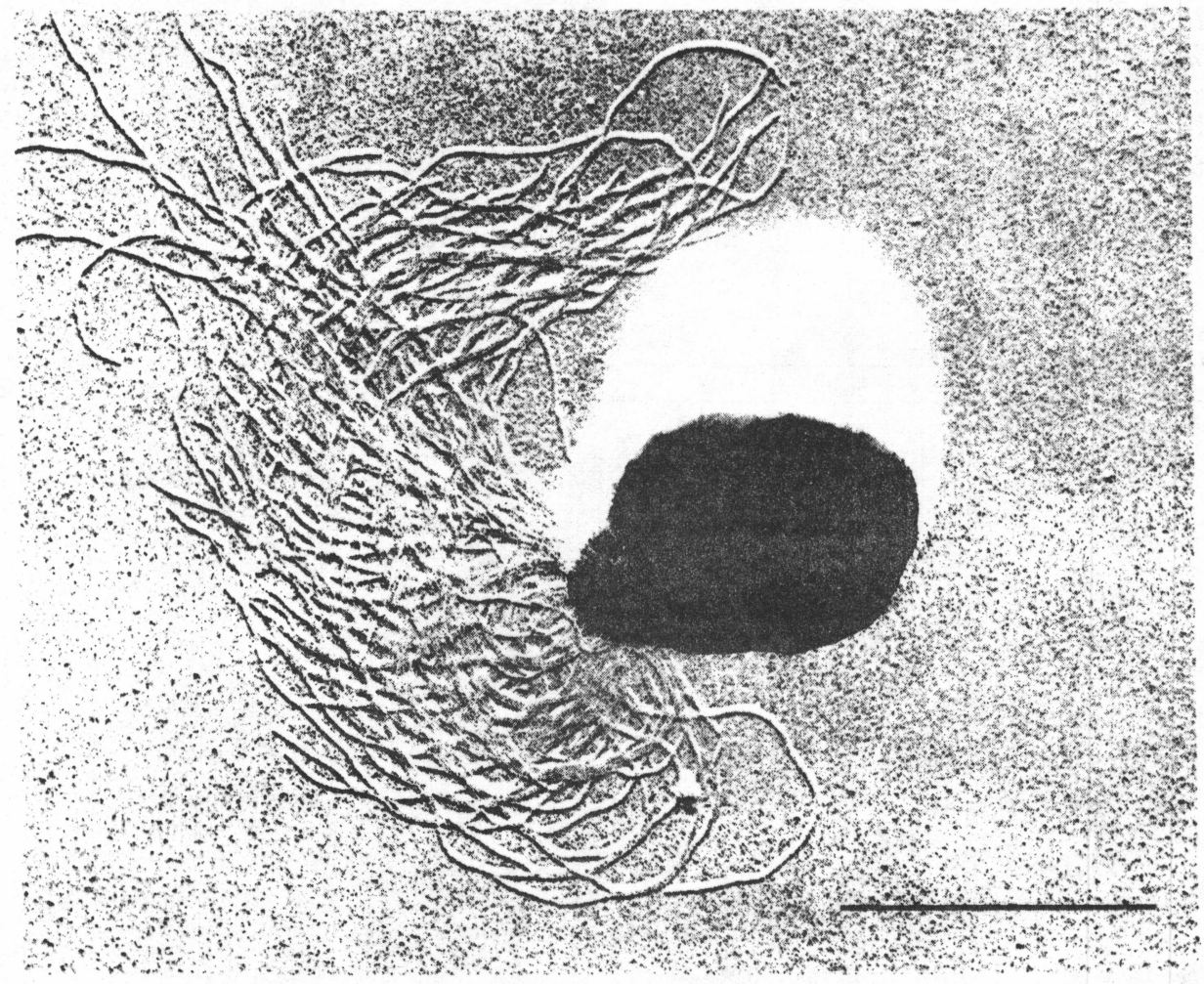

Figure 5. Prrococcus furiesus. EM micrograph, Pt-shadowing Bar $1 \mu \mathrm{m}$. 


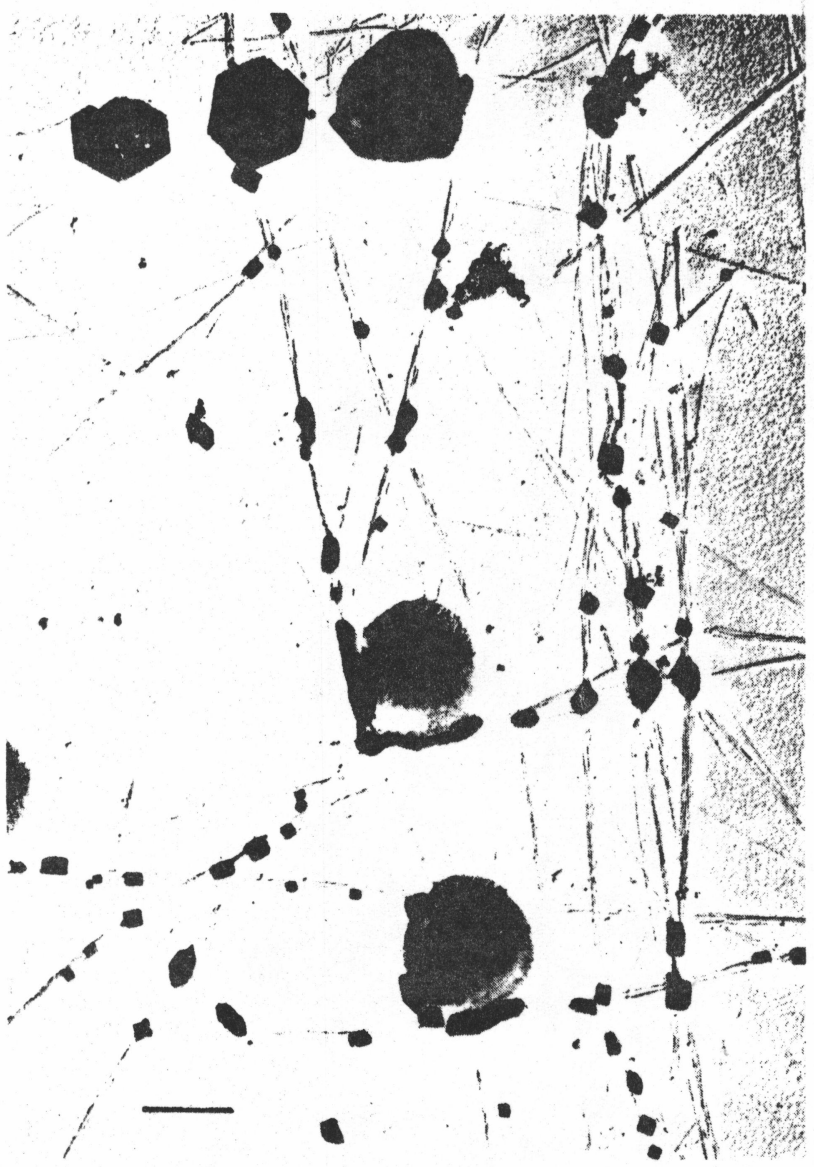

Figure 6. Pyrodictium occultum. EM micrograph, Pt-shadowing. Bar 1 $\mu \mathrm{m}$

under these conditions does not seem possible ${ }^{20,21}$. Although the upper temperature limit for life is still unclear, it is probably much lower than $250^{\circ} \mathrm{C}$, possibly in the range between 110 and $150^{\circ} \mathrm{C}$, at which heat-sensitive molecules could be successfully resynthesized.

Acknowledgment. We wish to thank Dr H. König for the preparation of electron micrographs.

I Baross, J. A., and Deming, J. W., Growth of 'black smoker' bacteria at temperatures of at least $250^{\circ} \mathrm{C}$. Nature 303 (1983) 423-426.

2 Bernhardt, (j., Lüdemann, H.D., Jaenicke, R., König, H., and Stetter, K.O., Biomolecules are unstable under 'black smoker' conditions. Naturwissenschaften $7 I$ (1984) $583-585$.

3 Brock, T.D., Thermophilic microorganisms and life at high temperatures. Springer Verlag, New York/Heidelberg/Berlin 1978.

4 Brock, T. D.. Brock, K.M., Belly, R.T., and Weiss, R. L., Sulfolohus: A new genus of sulfur oxidizing bacteria living at low $\mathrm{pH}$ and high temperature. Archs Microbiol. 84 (1972) 54-68.

5 Corliss, J. B., Dymond, J., Gordon, L. J., Edmond, J. M., Von Hercen, R.P., Ballard, R. D., Green, K., Williams, D., Bainbridge, A., (ranc. K.. and Van Andel, T. H., Submarine thermal springs on the (ialapatgos Rift. Science $2(13$ (1979) 10731083.

6 Fiala, (i., and Stetter, K. O., Prococcus furiosus sp. nov, represents a novel genus of marine heterotrophic archaebacteria growing optimatly at 100 ${ }^{\circ}$ ('. Archs Microbiol. 145 (1986) 56.61
7 Fiala, G., Stetter, K.O., Jannasch, H.W., Langworthy, T. A., and Madon, J., Staphylothermus marinus sp. nov. represents a novel genus of extremely thermophilic submarine heterotrophic archaebacteria growing up to $98^{\circ} \mathrm{C}$. System. appl. Microbiol. 8 (1986) 106-113.

8 Fischer, F., Zillig, W., Stetter, K.O., and Schreiber, G., Chemolithoautotrophic metabolism of anaerobic extremely thermophilic archaebacteria. Nature 301 (1983) $511-513$.

9 Huber, G., Huber, H., and Stetter, K.O., Isolation and Characterization of new metal-mobilizing bacteria. Biotech. Bioeng. Symp. (1986) in press.

10 Huber, R., Langworthy, T.A., König, H., Thomm, M., Woese, C. R., Sleytr, U. B., and Stetter, K.O., Thermotoga maritima sp. nov. represents a new genus of unique extremely thermophilic eubacteria growing up to $90^{\circ} \mathrm{C}$. Archs Microbiol. 144 (1986) 324333.

11 Kandler, O., and König, H., Cell envelopes of archaebacteria, in: The Bacteria. A Treatise on Structure and Function, vol. 8, Archaebacteria, pp.413-457. Eds C. R. Woese and R. S. Wolfe. Academic Press, New York/London 1985.

12 König, H., and Stetter, K. O., Studies on archaebacterial S-layers. System. appl. Microbiol. 8 (1986) 100-105.

13 Lauerer, G., Kristjansson, J. K., Langworthy, T. A., König, H., and Stetter, K.O., Methanothermus sociabilis sp. nov., a second species within the Methanothermaceae growing at $97^{\circ} \mathrm{C}$. System. appl. Microbiol. 8 (1986) $100-105$.

14 Segerer, A., Stetter, K. O., and Klink, F., Two contrary modes of chemolithotrophy in the same archaebacterium. Nature $313(1985)$ 787-789.

15 Stetter, K.O., Ultrathin mycelia-forming organisms from submarine volcanic areas having an optimum growth temperature of $105^{\circ} \mathrm{C}$. Nature 300 (1982) $258 \cdot 260$

16 Stetter, K.O., and Gaag, G., Reduction of molecular sulphur by methanogenic bacteria. Nature 305 (1983) 309-311.

17 Stetter, K.O., König, H., and Stackebrandt, E., Pyrodictium gen. nov., a new genus of submarine disc-shaped sulphur reducing archaebacteria growing optimally at $105^{\circ} \mathrm{C}$. System. appl. Microbiol. 4 (1983) 535-551.

18 Stetter, K.O., Thomm, M., Winter, J., Wildgruber, G., Huber, H. Zillig, W., Janekovic, D., König, H., Palm, P., and Wunderl, S. Methanothermus fervidus, sp. nov., a novel extremely thermophilic methanogen isolated from an Icelandic hot spring. Zbl. Bakt. Hyg. Abt. I. Orig. C 2 (1981) 166-178.

19 Stetter, K.O., and Zillig, W., Thermoplasma and the thermophilic sulfur-dependent archaebacteria, in: The Bacteria, vol. 8, Archaebacteria, pp. 85 170. Eds C. R. Woese and R.S. Wolfe. Academic Press, New York 1985

20 Trent, J.D., Chastain, R. A., and Yayanos, A. A., Possible artefactual basis for apparent bacterial growth at $250^{\circ} \mathrm{C}$. Nature $2(1) 7(1984)$ 737-740.

21 White, R.H., Hydrolytic stability of biomolecules at high temperatures and its implication for life at $250^{\circ} \mathrm{C}$. Nature 310 (1984) 430) 432.

22 Williams, H., and McBirney, A. R., Volcanology. Freeman, Cooper and Co., San Francisco 1979.

23 Woese, C. R., Gupta, R., Hahn, C. M., Zillig, W., and Tu, J., The phylogenetic relationships of three sulfur-dependent archacbacteriat. System. appl. Microbiol. 5 (1984) 97105.

24 Zillig, W., Stetter, K.O., Schäfer, W., Janekovic, D., Wunderl, S. Holz, I., and Palm, P., Thermoproteales: A novel type of extremcly thermoacidophilic anaerobic archaebacteria isolated from Icelandic solfataras. Zbl. Bakt. Hyg., Abt. I. Orig. C 2 (1981) 205227.

25 Zillig, W., Stetter, K. O., Wunderl, S., Schulz, W., Priess, W., and Scholz, I., The Sulfolobus - "Caldariella" group: Taxonomy on the basis of the structure of DNA-dependent RNA polymerases. Archs Microbiol. 125 (1980) 259-269.

$0014-4754 / 86 / 11 / 121187-05 \$ 1.50+0.20 / 0$

C) Birkhäuser Verlag Basel, 1986 